\title{
PENGARUH PENGGUNAAN VIDEO PEMBELAJARAN TERHADAP HASIL BELAJAR SISWA PADA MATERI GARIS DAN KONSTRUKSI GEOMETRIS
}

\author{
Darusman Hidayat ${ }^{1}$, Ono Wiharna ${ }^{2}$, Yayat $^{3}$ \\ Universitas Pendidikan Indonesia \\ Jl. Dr. Setiabudi No. 229 Bandung 40154 \\ daruzboy@gmail.com
}

\begin{abstract}
ABSTRAK
Tujuan penelitian adalah untuk mengetahui pengaruh penggunaan video pembelajaran terhadap hasil belajar siswa pada materi garis dan konstruksi geometris. Metode penelitian menggunakan pre-experiment design dengan one group pretest -posttest design. Variabel dalam penelitian ini yaitu: penggunaan media video dan hasil belajar siswa. Subjek penelitian adalah siswa kelas X TPU 9 di SMKN 12 Bandung. Sampel ditentukan dengan purposive sampling yang berjumlah 32 siswa. Teknik analisis data yang digunakan adalah paired sample t-test. Uji-t digunakan untuk mengetahui perbedaan tingkat hasil belajar siswa. Hasil penelitian diperoleh peningkatan nilai hasil belajar rata-rata sebesar 29,5. Peningkatan hasil belajar ( $\mathrm{N}$-gain) sebesar 0,4 yang masuk dalam kategori sedang. Hasil pengujian hipotesis terdapat pengaruh penggunaan video pembelajaran terhadap hasil belajar pada materi garis dan konstruksi geometris.
\end{abstract}

Kata kunci: video pembelajaran, garis, konstruksi geometris, hasil belajar

\section{PENDAHULUAN}

Sekolah Menengah Kejuruan adalah salah satu jenjang pendidikan menengah dengan kekhususan mempersiapkan lulusannya untuk siap bekerja. Pendidikan kejuruan mempunyai arti yang bervariasi namun dapat dilihat suatu benang merahnya. Pendidikan kejuruan sebagai bagian dari sistem pendidikan yang mempersiapkan seseorang agar lebih mampu bekerja pada suatu kelompok pekerjaan atau satu bidang pekerjaan daripada bidang-bidang pekerjaan lainnya.

Salah satu mata pelajaran dari program keahlian khusus ini adalah mata pelajaran gambar Teknik. Gambar Teknik merupakan mata pelajaran yang termasuk kelompok program $\mathrm{C} 1$ atau kelompok Mata Pelajaran Dasar Bidang Keahlian. Mata pelajaran ini menuntut siswa untuk memiliki kemampuan membaca gambar (Dahar, 2011). Mata Pelajaran Gambar Teknik memiliki beberapa materi salah satunya adalah materi garis dan konstruksi geometris diajarkan di semester ke-I kelas X. Materi ini membahas pengenalan bentuk dan fungsi garis seperti garis gambar, garis sumbu, garis ukuran, garis potongan, garis bantu dan lainnya. Selain pengenalan garis, materi ini membahas tahapan dalam menggambar konstruksi geometris.

\footnotetext{
${ }^{1}$ Mahasiswa Departemen Pendidikan Teknik Mesin FPTK UPI

2 Dosen Departemen Pendidikan Teknik Mesin FPTK UPI

${ }^{3}$ Dosen Departemen Pendidikan Teknik Mesin FPTK UPI
} 
Proses pembelajaran materi garis dan konstruksi geometris haruslah student centered. Hal ini sesuai dengan kurikulum 2013 yang menuntut siswa aktif, kreatif dan inovatif dalam pemecahan masalah. Selain itu, kebutuhan akan sarana dan prasarana seperti kondisi kelas yang representatif, alat gambar yang lengkap dan media pembelajaran yang jelas dan komprehensif harus terpenuhi (Daryanto, 2013). Pada silabus, materi garis dan konstuksi geometris secara spesifik menuntut siswa untuk aktif dalam mengamati materi, menanyakan permasalahan, mengeksplorasi data, dan mengkomunikasikan hasil konseptual secara lisan maupun tulisan. Selain itu, guru dituntut untuk menjelaskan materi ini dengan langkah yang cermat dan runtut hingga siswa memahami materi tersebut.

Di SMKN 12 Bandung, materi proses belajar materi garis dan konstuksi geometris diajarkan di kelas gambar. Kelas gambar tersebut mampu menampung hingga 40 siswa. Kelengkapan sarana dan prasarana cukup memadai seperti proyektor, papan tulis hingga meja gambar. Proses belajar mengajar dimulai dengan penjelasan materi, demonstrasi menggambar di papan tulis, eksplorasi siswa dan penugasan (Hubies, 2007). Dalam waktu 2 jam pelajaran, guru menghabiskan 1 jam pelajaran untuk pematerian dan sisa waktu digunakan untuk eksplorasi siswa.

Media yang digunakan guru ketika melakukan proses pembelajaran menggunakan media papan tulis. Dalam pengamatan, terlihat siswa kesulitan mengikuti demonstrasi guru dalam menggambar garis dan konstruksi geometris di papan tulis. Banyak siswa kurang bisa mengeksplorasi tugas yang diberikan guru dikelas. Nilai kompetensi materi garis dan konstuksi geometris menunjukkan bahwa 57\% dari 62 siswa masih belum mampu mencapai KKM (Nilai KKM 7,5). Data tersebut menjelaskan bahwa banyak siswa yang tidak mengerti materi garis dan konstruksi geometris (Purwanto, 2009). Rendahnya pemahaman siswa akan materi ini adalah karena media pembelajaran yang digunakan guru kurang optimal. Dalam media papan tulis, guru hanya menjelaskan 2 hingga 3 kali bagaimana sebuah garis dan konstruksi geometris digambar.

Keadaan seperti ini menuntut para guru selaku tenaga pengajar untuk dapat menciptakan proses pembelajaran yang cocok dan sesuai dengan kondisi siswa, salah satunya adalah dengan pola student centered dengan menyediakan sumber atau media pembelajaran yang dapat dipelajari baik di lingkungan sekolah maupun di rumah khususnya untuk bahan pelajaran pada mata pelajaran Menggambar Teknik. 
Alternatif media pembelajaran yang sesuai dengan permasalahan di atas adalah dengan mengganti atau menambah media pembelajaran untuk meningkatkan pemahaman siswa. Media pembelajaran tersebut adalah video. Pembelajaran dengan video lebih menekankan peran aktif siswa, para siswa dapat melaksanakan proses pembelajaran sesuai dengan kemampuan dan kecepatan belajarnya masing-masing (Riyana, 2009). Selain itu, video dapat memuat tahapan menggambar menjadi lebih komprehensif dan dapat diputar berulang.

\section{METODE PENELITIAN}

Metode penelitian yang digunakan adalah Pre-Experimen Design. Dalam desain ini, tidak menggunakan variabel kontrol (kelas kontrol) dan sampel tidak dipilih secara random. Preexperimental design belum merupakan eksperimen sungguh-sungguh, karena masih terdapat variabel luar yang ikut berpengaruh terhadap terbentuknya variabel dependen. Jadi, hasil eksperimen yang merupakan variabel dependen itu bukan semata-mata dipengaruhi oleh variabel independen. Penelitian ini menggunakan pre-experimental design dengan bentuk one group pretest-posttest design.

\section{HASIL PENELITIAN}

Hasil pretes diperoleh sebesar 26,09 dan hasi pos test yaitu 55,63. N-gain, diperoleh nilai 0,40 yang masuk dalam kategori sedang. Hasil uji t menunjukkan bahwa penggunaan video pembelajaran berpengaruh terhadap hasil belajar siswa pada materi garis dan konstruksi geometris. Berpengaruhnya media video terhadap hasil belajar tidak terlepas dari karakteristik video itu sendiri. Media video termasuk ke dalam kelompok keempat dengan karakteristik media yang penyampaian pesannya dapat diterima melalui indera pendengaran dan penglihatan, penyampaian audio visual yang dapat diulang diperlambat maupun dipercepat. Media video ini berisi konten text, suara, musik, gambar atau visual yang statis dan dinamis, sehingga dalam proses pembelajarannya melibatkan banyak indera.

\section{PEMBAHASAN}

Semakin banyak alat indera yang digunakan untuk menerima dan mengolah informasi, semakin besar kemungkinan informasi tersebut dimengerti dan dapat dipertahankan dalam ingatan (Arsyad, 2013). Selain itu karakteristik lainnya adalah media video dapat diputar dengan 
menggunakan video player, sehingga penyajian materi dapat dikontrol dengan dijeda, dipercepat diperlambat ataupun diulang (Yuliani, 2015). Media video memiliki potensi yang cukup besar jika dimanfaatkan sebagai media pembelajaran yang memungkinkan peserta didik dapat mengamati langsung tentang wujud suatu benda, mengamati proses perubahan, mengamati suatu perbedaan warna dan mengamati suatu gerakan dan lain-lain yang diiringi dengan suara (Warsita, 2010).

Selain berpengaruhnya video terhadap hasil belajar, antusias siswa lebih terlihat ketika peneliti mulai memberi pelajaran dengan menggunakan video (Ojeme, 2008). Pada saat peneliti sedang mempersiapkan peralatan yang digunakan untuk memutar video, siswa sudah merasa senang dan penasaran apa yang akan ditampilkan. Hampir semua siswa memperhatikan dan mengamati video yang diputar. Terjadi interaksi yang positif antara peneliti dan juga siswa. Siswa dapat dengan mudah memahami materi yang dapat di lihat pada diktat yang diberikan oleh guru (Rusman, 2012). Banyak siswa yang mendapat nilai baik namun masih ada juga siswa dengan nilai yang kurang baik.

Media video sesuai untuk kompetensi dasar garis dan konstruksi geometris, karena media video membawa konten beragam yang dicerna banyak indera (Sainsbury, et. al., 2016). Hal yang menjadi penilaian penting selain berpengaruhnya video terhadap hasil belajar dalah media video tidak memberikan nilai $N$-Gain yang tinggi (Arifin, 2009). Dalam perhitungan N-Gain, termasuk pada kategori sedang, perhitungan tersebut menunjukan masih adanya kekurangan dalam media video.

Media video memiliki batasan dalam interaksi (Susilana dan Riyana, 2009). Siswa hanya bisa melihat namun tidak bisa berinteraksi secara langsung. Tidak adanya interaksi 2 arah dalam media video menjadikan media video kurang interaktif. Kelemahan lainnya, karena media video tidak memiliki interaksi 2 arah, media ini tetap perlu dipandu oleh guru agar video tersebut lebih dipahami oleh siswa. Interaksi dengan panca indera, video merupakan media yang dapat didengar dan dilihat (Hasanah, 2017). Jika kita melihat kerucut pengalaman Edgar Dale, maka daya ingat siswa terhadap media video berkisar 30\%. Hal tersebut juga menjadi alasan mengapa $N$-Gain media video berada dalam kategori sedang. 


\section{KESIMPULAN}

Kesimpulan penelitian ini yaitu penggunaan video pembelajaran berpengaruh terhadap hasil belajar siswa SMK pada materi garis dan konstruksi geometris. Media video dapat digunakan menjadi media pembelajaran materi garis dan konstruksi geometris, sehingga dapat meningkatkan motivasi dan hasil belajar siswa.

\section{REFERENSI}

Arifin, Z. (2009). Evaluasi Pembelajaran. Bandung:PT. Remaja Rosdakarya.

Arsyad, A. (2013). Media Pembelajaran. Jakarta: PT Raja Grafindo Persada.

Dahar, R. W. (2011). Teori-Teori Belajar dan Pembelajaran. Jakarta: Erlangga.

Daryanto. (2013). Strategi dan tahapan mengajar (bekal keterampilan dasar bagi guru). Bandung: CV Yrama Widya.

Hasanah, M. (2017). Pengaruh Video Pembelajaran terhadap Hasil Belajar pada Sub Materi Sistem Hormon. Jurnal Pendidikan dan Pembelajaran, 6 (2). http://jurnal.untan.ac.id/indx.php/jpdpb/article/view/18553/15649.

Hubies, A. (2007). Pengaruh Desain Pesan Video Instruksional terhadap Peningkatan Pengetahuan Petani tentang Pupuk Agrodyke. Jurnal Pertanian. http://dx.doi.org/10.21082/jae.v25n1.2007.1-10. [10 Oktober 2017].

Ojeme, C. (2008). Influence of Video Learning on Sex Education Towards Eradicating AIDS in Africa. Proceedings of World Conference on E-Learning in Corporate, Government, Healthcare, and Higher Education. 66(2). ISBN 978-1-880094-66-2. https://www.learntechlib.org/p/29985/.

Purwanto, M. N. (2009). Evaluasi Pengajaran. Bandung: PT Remaja Rosdakarya.

Riyana, C. (2009). Pedoman Pengembangan Media Video. Jakarta: P3AI UPI.

Rusman. (2012). Model-Model Pembelajaran. Depok: PT Rajagrafindo Persada.

Sainsbury, J. Telgarsky, B., Parotto, M. (2016). The effect of verbal and video feedback on learning direct laryngoscopy among novice laryngoscopists: a randomized pilot study. Canadian Journal of Anesthesia. [Online] https://link.springer.com/article/10.1007/s12630-016-0792-. [10 Oktober 2017]

Susilana dan Riyana, C. (2009). Media Pembelajaran: Hakikat, Pengembangan, Pemanfaatan, dan Penilaian. Bandung: CV Wacana Prima. 
Warsita, B. (2010). Teknologi Pembelajaran Landasan \& Aplikasinya. Jakarta: Rineka Cipta.

Yuliani, D. (2015). Pengaruh Video Pembelajaran terhadap Kemampuan Berhitung Permulaan Anak Kelompok B di Taman Kanak-Kanak. E-joural Pendidikan Anak Usia Dini. 5(1). https://ejournal.undiksha.ac.id/ index.php/JJPAUD/article/download/11309/7226. 